\title{
Freedom Domination of Rabindranath Tagore's Freedom Poetry: A Postcolonial Approach
}

\author{
Haris Prasetya Effendie \\ English Literature Department \\ Universitas Ahmad Dahlan \\ Indonesia \\ haris1800026235@,webmail.uad.ac.id
}

Citation: Effendie, H. P. (2021). Freedom domination of Rabindranath Tagore's freedom poetry: A postcolonial approach. Notion: Journal of Linguistics, Literature, and Culture, Vol 3(1), p. 30-43. http://doi.org/notion.v3i1.3689

\begin{tabular}{|c|c|}
\hline Article Info & ABSTRACT \\
\hline $\begin{array}{l}\text { Article History } \\
\text { - Article Received } \\
16^{\text {th }} \text { February } 2021 \\
\text { - Article Accepted } \\
21^{\text {st }} \text { April } 2021 \\
\text { Keywords } \\
\text { Connotation } \\
\text { Denotation } \\
\text { Freed } \\
\text { Postolonialism } \\
\text { Summary }\end{array}$ & $\begin{array}{l}\text { All types made war and Independence of imperialism movement plots. A vast place } \\
\text { that contained natural resources and people as the tribe was victimized to create the } \\
\text { movement. Postcolonialism tells the wealth as freed to the motherland. The } \\
\text { motherland or kingdom of great nationalism was called, and significant attention to } \\
\text { the nationalism day to pay the bitter national history with prayer. Kingdom of human } \\
\text { life is wealth because the years have been calling humans to study political relation, } \\
\text { nationalism relation, and nationalism knowledge. Case of war and how the wealth is } \\
\text { always in upper domination are how poetry as a literary work reflects the soul of } \\
\text { cultural hope and denotation in the poetry line. Wealthy is the most appropriate } \\
\text { statue to know the social life. The nationalism knowledge is freed because the } \\
\text { structure of greatness that humans must study is education to speak about wealth. } \\
\text { Descent aspect was ordered to the nation's identity, but no less to join the political } \\
\text { descent to restart the freedom to some nation-the wisdom from any discipline to } \\
\text { grow and refresh the freedom identity about nature and humanity. India has the } \\
\text { national history as Indonesia when Rabindranath Tagore also talks about how the } \\
\text { country speaks about all the day long nationally wealth in his poetry to next their } \\
\text { life. The research was qualitative research to apply the Postcolonialism theory. }\end{array}$ \\
\hline
\end{tabular}




\section{Effendie, Haris Prasetya \\ Freedom Domination of Rabindranath Tagore's Freedom Poetry: A Postcolonial Approach}

\section{INTRODUCTION}

Wiryawan in Faruk[5] spells the meaning that concept is meant to show objects or empiric processing. He grows the example that the concept can tell as an abstraction result from objective experience that according to has similarity especially, it also could to call as a scientific thinking result which shows to objects and empiric processes indirectly. Theory, of course, does not only function as a partner unit for conceptualization, but it is also part of a practical problem replacing in conceptual framework especially that implicated each relation between a concept from others, each fact from others. Poetry and postcolonialism are two different concepts those spell as new research here.

Colonial-era happened as expedition or resources brutal struggle imperialism in Asia countries other Africa, America. Western as the new light of postcolonialism influenced in natives and natives fight their mainland and all components too much in much significant. Symbolization is almost identical to any native every country after ethicality some nation in Asia socially. Socially period was structured more than 100 years to spell in imperialism fight.

Ratna[13] spoke that all undergraduate students agree that all country areas, whichever happened colonialism age, have the problem too much, and it was analyzed in postcolonial theory. Ashcroft et al., in Ratna[13], gave an example to put the central their mind in English action with India, Africa, Australia, Canada, and Caribbean postcolonial conditions.

Pakistan bordered India or Bharat, a country that occupies the more significant part of South Asia. In the east, the Islamic Republic of Iran in the west, Ocean Hindi in the south, and the Republic of China in the north. Its capital is New Delhi, and Mumbai, as a most prominent city, builds in the 20th century just south of the historic hub of Old Delhi to serve as India's administrative center. Britainnica.com sent that direct administration from the British, which began in 1858, effected a political and economic unification of the subcontinent in the Hinduism country[1]. India speaks of the independence day on August 15, 1947, as the dominion, and January 26, 1950, as a republic with the Rupee monetary unit.
India has a parliament as the legislature, which is ordered in the upper and lower house.

India has a history of war after Independence. It was a period of rebellions in northern and central India against the British power in 1857-1858 in according to Britannica[1]. The first war in India, called Indian Mutiny or the Sepoy Mutiny, is known as new colonialism that gives birth the nationalism in India. The British usually refer to it as widely acknowledged as the first-ever united rebellion against colonial rule in India. A Sepoy in the British colonial army, Mangal Pandey was the spearhead of this revolt, which started when Indian soldiers rebelled against their British officers to violate their religious sensibilities[1].

The sensibility of nationalism explained that country follows the legacy or any research and sciences to build the nation. Point of view talks to build the union from ideology as national progress. A degree of faith was colonized from how much the nation and personal aspect were answered from a treat and the function of government operations from the president, ministry. Colorful columnizing is attended to by the chairs of the legislature as to how the country creates the rules and ideology system. The sensibility of nationalism is according in the united ideology some area.

Nationalism created one characteristic that has also been victimized a long time, but life plot and phrase tell the remarkable history from the national aspect. Wealth in nationalism is how society has notes to deliver the record of lessons and legacy to the next age as the significant cultural national. The prestige of nationally appropriate is not only a significant introduction in a nation or a tribe just because of the central figures. Life's material is much to speak the identity. However, the cross character could answer it, and it is talked about minority and majority, but the strong hands to bring the national gold to the next age as a free country. Nationalism is explaining the direct cause of colonialism[13].

The western colony came as a company to take resources and pay the highest tax on natives. Imperialism rises as dangerous in the past of the nation. India wrote history as the great Hindus 
majority in the world. Descent of India as next researcher and people in the millennials age in industry 4.0. A nation remembered imperialism as the new Renaissance.

According to Jensen in Ratna[13], the Renaissance era delivered the most advance minimally four aspects: literary, arts, sciences, and religion. Then, Renaissance has known as the rising age of humanity value individuals in one group, Ancient Greek cultural values, and ancient Roman cultural values called classic cultural in other subjects. Imperialism could be an indirect symbol of how great a nation looks for some area as a significant identity. According to Indonesian history, imperialism explained how a great nation looks for lands in the gold, glory missions.

Begun in Meerut city of Indian troops (sepoys) in the British East India Company service, it spread to Delhi, Agra, Kanpur, and Lucknow. Philosophy of life grows and teaches how life could deliver an era to speak and write the glorious moment. The legacy of nationalism is called spirit and revolution. Ideologically, Rabindranath Tagore, as an Indian, called the country the motherland.

1857-1858 are the time to India speaks to a dynamic nationalism. They as Sepoy Mutiny to speak the freedom from a powerful ideology. Soldiers and other owners are uniting one ideology, after the British-the years of postcolonial, for India as a country in the building. The dominion as the heroic moment is made finally to India on August 15, 1947.

Large Sections of Hindus, Muslims, and Sikhs together challenged Britain's most extraordinary imperialist power during India's first war of Independence, which began on May 10, 1857. Naturally, this extraordinary unity unnerved the franchise. It made them realize that if their rule continued in India, it could happen only when Hindus and Muslims, the two largest religious communities, were divided along communal lines, as Islam said[1]. This is a historical-cultural that nationalism was begun.

\section{Rabindranath Tagore Biography}

Rabindranath Thakur was born as a Bengali poet. Rabindranath Tagore (1861-1941) talked about the atmosphere of India reflected how the universe becomes the witness of the writer in readers[12]. During the time, the action can be drawn as the figure of age and symbol of nationalism because of how much memory could contain between ideology, nationalism, and soul of feeling so the spirit of Independence could begin. Anderson said, "He was highly influential in introducing Indian culture to the West and vice versa, and he is generally regarded as the outstanding creative arts of early 20th century India[1]. In 1913 he became the first non-European to receive the Nobel Prize for literature[15].

The son of the religious reformer Debendranath Tagore, he early began to write verses, and, after preliminary studies in England in the late 1870s, he returned to India[15]. He could begin the literary work because of his spirit to reflect between the history of nationalism and the religion that contains God and God's serves. Nevertheless, Rabindranath Tagore published Manasi (1890). This collection marks the maturing of his genius. It contains some of his best-known poems, including much in verse forms new to Bengali and some social and political satire that was critical of his fellow Bengalis[15].

Wonderful time explained that from 1912 Tagore spent long periods out of India, lecturing and reading from his work in Europe, the Americas, and East Asia and becoming an eloquent spokesperson for the cause of Indian Independence. Then, in 1918 Rabindranath Tagore said in an address delivered at the university he finds on his 70s birthday, "I have it, it is true, engaged myself in a series of activities. But the innermost me is not to be found in any of these. Finally, at the end of the journey I am able to see, a less much clearly, the orb of my life. Looking back, the only thing of which I feel certain is that I am a poet". 


\section{Effendie, Haris Prasetya \\ Freedom Domination of Rabindranath Tagore's Freedom Poetry: A Postcolonial Approach}

\section{Allegory}

Textually, the sentence as to how writer speaks and show any evidence in writer's literary work. The clause is containing evidence and connotation as allegory and narrative. Allegory in literary work usually was written by the writer's atmosphere and the universe. Form of connotation contains the concluding moral value by point of view as nationality some country and life that was explained from the writer either eastern and western. Extending of an allegory is according to the quote, "Allegory is a form of extended metaphor in which objects, persons, and actions in a narrative, either in prose or verse, are equated with meanings that lie outside the narrative itself' (Holman in Setiowati and Wardani[17]).

How allegory to speak and clauses tell the rule of the universe from the writer's literary work? From the quote, it was answered that "allegory and metaphor are both literary devices or figures of speech that will improve your writing. Allegory and metaphor, as literary devices may seem similar, but they're not exactly the same. Many writers and speakers as well use metaphor and allegory regularly, but often without knowledge of what they are and how they work. Skilled writers know the differences and how to wield each one well (Bryan, 2020)".

Leyburn in Setiowati and Wardani[17] said an allegory becomes political if it covers a political event or situation from producing a subtle commentary on it using other symbols. The term political allegory can also be applied to fictional characters as direct substitutions for honest politicians.

Metaphors are literary devices that compare two unrelated objects[3]. It describes something from comparing it to something that it is not. It makes the comparison without using the word "like" or "as". A metaphor describes a single idea or symbol. It is short, often finished in one phrase or paragraph, never carried through the entire piece of writing.

Holman in Setiowati and Wardani[17] also explained that "an allegory the objective referent evoked is without value until it is translated into the fixed meanings that it has in its own particular structure of ideas." Boyd in Setiowati and Wardani[17] also argued that even if allegory is generally considered a continuation of metaphor, no continuation of metaphor ever becomes an allegory. Therefore, Setiowati and Wardani[17] translated it connotative, that Boyd explains that several essential properties distinguish allegory and metaphor.

\section{Alliteration}

Textually, how some voice or consonant is the same as other consonants in different words and lines is called alliteration. Munthe and Lestari[11] explained that alliteration is about repetition of the initial consonant sound for the following word. Holman in Setiowati and Wardani[17] also explained that "an allegory the objective referent evoked is without value until it is translated into the fixed meanings that it has in its own particular structure of ideas."

\section{Personification}

Textually, to know the lines of poetry that show something other human does anything like human characteristics [3]. So it is personification because it comes to spell something from the soul. Therefore, humans as the reader can understand what it means when an actor of poetry gives something to the thing.

\section{Postcolonialism}

Postcolonialism, the historical period or state of affairs representing the aftermath of Western colonialism; the term can also be used to describes the concurrent project to reclaim and rethink the history and agency of people subordinated under various forms of imperialism[7]. Postcolonialism signals a possible future of overcoming colonialism, yet new forms of domination or subordination can come in the wake of such changes, including new forms of global empire. Postcolonialism should not be confused with the claim that the world we live in now is devoid of colonialism.

Said[16] explained carefully the second index of how inclusive Orientalism had become since the Council of Vienne finds in 19th-century chronicles of the field itself. He spoke that not until quite late in the country, with the single major exception of Napoleon's Institute d'Egypte, was much attention given the academic study of the modern, or actual, Orient. Moreover, he said the Orient Studied was a textual universe from and large; the impact of the 
Orient was made through books and manuscripts, not, as in the imprudence of Greece on the Renaissance, through mimetic artifacts like sculpture and pottery.

Moreover, Orientalist studies cover everything from the editing and translation of texts to numismatic, anthropological, archaeological, sociological, economic, historical, literary, and cultural studies in every known Asiatic and North African civilization, ancient and modern.

Postcolonialism in this research was applied to view the findings on close reading and reconstructive reading of Tagore's "Freedom" poetry. In Kusumaningrum and Mulyani[9], Kennedy and Gioia tell that close reading is the required method of formalist criticism used to unfold a poem. Close reading is how doing conducted by analyzing a poem carefully step by step and exemplifying it. Together it has the purpose to show the combination of various elements in a literary work affects readers. Formalist criticism believes that various stylistic elements influence thematic elements and vice versa; both form and content could not separate because they would destroy meaning.

Said[16] also repeated the meaning that Even the rapport between an orientalist and Orient was textual in the meaning it is so much that so it is reported of some of the early-nineteenth-century German orientalists that their first view of an eight-armed Indian statue cured them entirely of their Orientalist taste. It was said from him because when a learned Orientalist traveled in the country of his specialization, it was always with unshakable abstract maxims about "civilisation" then he had studied; rarely were orientalists interested in anything except proving the validity of these musty "truths" from applying them, without great success, to uncomprehending, hence degenerate, natives.

Cultural and postcolonial literature as two different theories that show the evidence of glorious meaning as exceptional moral value and witness and science to tell the struggle naturally on the writer's poetry, setting on the writer's poetry. Ratna[13] wrote, "Science is not myth, it doesn't belong to special race ... but science is belong to human overall, it could be given from anyway who already to be diligent and find it". Sciences were understood as the profile of personality and a part of ideology, during research sincerely attended by the legislature as the subject of structural nationality rights in nationality aspect some country.

Ratna[13] said that "As variants postmodernism, postcolonialism, and following the statement multiculturalism clearly to face that difference as main conflict". Postcolonialism tells a year after the colonialization of some countries and reacts in nationality custom and religious communication projects. Different in literary work and it was researched with postcolonialism approach, to look for the theory and researcher achieves new theory and finds a new object, from the old object. The researcher looks for the new object, and it also has other dimensions to researcher finds as conclusion or concluding remark. Ratna sends on his book that definitively, the theory is a way of object understanding that was helped from method and technic.

Said[16] explained that the nexus of knowledge and the power of creating "the Oriental" and sense obliterating or removing all signs of something to him as a human being is not for Said an exclusively academic matter. He wrote that "Yet it is an intellectual matter of some undeniable importance. He wrote that he has been able to use his humanistic and political concerns to analyze and describe a very worldly matter, the rise, development, and consolidation of Orientalism.

\section{Postcolonial Literature}

Evidence of atmosphere in a postcolonial age, either written or spoken, was concluded from the history and how the relation to compare among writer, a universe, and reader socially. Literature never dies because there is much point of view, nextgeneration, writers' cross era. The whole of the world looks for postcolonialism from literature. Ratna[13] spoke about postcolonial literature "There is difference between postcolonial and cultural literature, like: India literature, Arabic, Persian, and Malay". In essence, he continues that it is like, in essence, postcolonialism literature is the literary work 


\section{Effendie, Haris Prasetya \\ Freedom Domination of Rabindranath Tagore's Freedom Poetry: A Postcolonial Approach}

that, according to colonialism hegemony, cultural literature is the identically spread of culture.

The main problems discussed throughout this research are (1) what is freedom domination does Tagore's "Freedom" display on different reading levels? (2) how does the nationalism spirit in Tagore's poetry contribute to the problem of Ratna's comparison of postcolonialism literature and cultural literature categories and other suitable quotes? This research applies postcolonialism as the approach of the study. The approach agrees with Tagore's "Freedom," the object of the study, which concerns nationality issues and subjectivity.

Said[16] also said that too often, literature and culture are presumed to be politically, even historically innocent; it has regularly seemed otherwise to me. Indeed, the study of Orientalism has convinced him that society and literary culture can only be understood and studied together.

\section{METHODOLOGY}

This qualitative research used an expressive approach to learn the superior moral value in the poetry of Tagore's poetry Freedom. The research was taken from the poetry line as a research sample, to translate from connotation and denotation, and postcolonial theory relation and book of research method, from Ratna[13] Postcolonial Indonesia: Relevansi Sastra, and Faruk[5] entitled Metode Penelitian Sastra: Sebuah Langkah Awal. This is a data analysis of explanation from observation of poetry analysis to find the meaning of each line.

\section{RESULT AND DISCUSSION}

Nationality is the official right to belong to a particular country, a group of people of the same race, religion, tradition[4]. Nationality is the aspect that supports any evidence of country postcolonial to explain the nation and descent when people or human was born to the world because it contained with destruction as a structure of identity. The political history and decline to acknowledge someone to rights and the law as nationality.

Gammon[6] speaks that freedom is the power or right to act, speak, or think as one wants without hindrance or restraint, and the absence of a despotic government. Freedom of the press prohibits the government from interfering with the printing and distribution of information or opinions. Press is a traditional media and human public speaking area to how something comes and rise to a general question as answers. It is always spoken about a requirement to any public necessary as leadership, study exchange, chronology, legacy, and election participation. Press and credibility always on one way.

Gammon[6] achieved that freedom of the assembly, sometimes used interchangeably with the freedom of association is the individual right to come together and collectively express, promote, pursue and defend common interests. The right to freedom of association is recognized as a human right, a political freedom and a civil liberty. This freedom can be limited from laws that protect public safety. Civil has understanding as the government begins the legislature's rule because civil of some country has an idea, grow, and business each other.

Gammon[6] advanced the meaning of expression freedom from freedom of expression includes freedom of speech, of the press, of association, of assembly and petition. This freedom doesn't extend to expression that defames, causes panic, creates fighting words, incites people to crime, creates sedition, or is obscene. Speech is the method of freedom, peace, and appointment of genres after critical thinking.

Gammon[6] advanced the meaning of speech freedom complete from "freedom of speech is the right of people to express their opinions publicly without governmental interference. The right doesn't extend to hate speech, advertising child pornography, and a few other instances".

Gammon[6] spelled that "freedom of religion is the freedom of an individual or community, in public or private, to manifest religion or belief in teaching, practice, worship, and observance. This right extends to any religious belief, but not in the practice of all religious activities (for example, ones that involve breaking other laws)". Freedom of religion as to how to act and do the worships according to religious faith, and religion as faith, saying, and prayer has been 
rising the image of the point of view to socialization, advancing on eastern of course on India.

Ratna[13] explained that nationality spirit, love to the motherland, and too much consciousness that accompanies political struggle need to be achieved from the culture in education. She wrote, "Without education, politic struggle is just gives birth no meaning motto, propaganda in it scrolling need to much to a part of majority". Ratna[13] added that culture was often discussed nationally, even as the central issue of critical treasure.

\section{Connotation and Denotation}

Connotation and denotation are easy comparisons about translation and speech of some sentences in literary work. The natural connotation is how to spell enough to the audience or reader from the universe. MasterClass[10] spoke basically, "One of the best ways to do this is through connotation, a literary device that refers to the selection of a word or phrase for its suggested meaning instead of its literal one. It is the difference between referring to an adult as 'youthful' versus 'childish': the definition of the words is the same, but the implied meaning is very different".

MasterClass[10] explained connotation as using a word to suggest a different association than its literal meaning, known as denotation. Connotations can be either positive, negative, or neutral.

Wellek and Rene Wallen in Faruk [5] explained that literary work replaced language. He also wrote that literary work material is different from other artwork. It is not a death work, but the human work added with the cultural legacy of some linguistic group.

\section{$I$ in Freedom}

The point of view on the poetry is first. I, as a subject, tell the field of literary work and a working soul. A main of viewpoint, I as feeler and adorer to the country as his motherland and other happening in the example the burden of ages, how they feel the trauma of colonialism or imperialism. He shows from the first line how the leading soul creates the acknowledge from his country and social love of the country from his understanding and rights. Socially, postcolonialism is the era that technology used and to help some conditions of nationalism. Domination of freedom is how the figures tell what they feel in the manuscript. The nationality consciousness can be symbolized as a royal place, full of glorious equality in society socially.

Klarer[8] spoke that "The term point of view, or narrative perspective, characterize how a text presents persons, event, and settings". He wrote that "The subtleties of narrative perspectives developed parallel to the emergence of novel and can be reduced to three basic positions: the action of the text is either mediated through a person involved in the activity (first-person narration) or presented without additional commentary (figural narrative situation).

Ratna[13] awares that nationality consciousness in the postcolonial framework is different from generally meaning. She said that first consciousness is to cause work ethic, confidence, possibly sympathy. Second consciousness is to rise patriotic acting, revenge, antipathy, anger, and hate feeling.

Ratna[13] wrote that postcolonial consciousness turns to the intellectual, not impacting emotionalism. Ratna explains that the reason it is colonial in whole the world was over, therefore possibly colonials were conscious about their mistake. She finally added revenge is no proper; meanwhile, cooperation is so important. His interpretation is postcolonial consciousness is a visible symptom to the surface, as since it was no important becomes a significant necessity. How to express the intellectual postcolonial? It is walked from spirit in nationalism and effort to spell the understanding in science what ones' study.

Ratna[13] spelled that a feature of postcolonial can be shown from domination, hegemony, and biner opposition, meanwhile culture literature feature is equality, similarity in both culture. She explained that first, it contained degradation elements; therefore, it rose the others, hybrid. The most decisive conflict in postcolonial literature, on the other side, dominated elements in culture literature, is assimilation, acculturation, and essence. She spoke that "Postcolonialism as other theory is understand of features".

Ratna[13] also explained that postcolonialism theory has not the following statement to colonialism 


\section{Effendie, Haris Prasetya \\ Freedom Domination of Rabindranath Tagore's Freedom Poetry: A Postcolonial Approach}

in practical political meaning. Therefore, an approach is a way to find the new object as effecting, thinking of actor, thing, new identity, and the final figure's doing.

Faruk [5] spoke in his book that "Humanly literary critic is according in a part of discursive formation what gives birth and to advance since first of 14 th century in Europe, it is discourse formative to effort of human being free from "waiting" philosophy system and society cultural 'middle age' what replaces human, collective or individuals under depression". $\mathrm{He}$ wrote that humanism is the first part of modernism. The second part is brightening that also explains discourse formation subjectively to subjectivity. India has a history of national as Indonesia and Malaysia. India as a Britain colonialism area truly high in nationalism either India native languages is advancing or generally federal building.

Ashcroft and friends in Ratna[13] announced that India was superior to other postcolonial from reason, to India natives to write in the motherland language, mother language. It was interesting from the English language. The reality also shows that the Indian nationalism spirit was more considerable, either it according to native speaker languages most advancing, or national building generally. Rasalah theory was thought of as the including influential. The Rasalah was talked from much dialogue since 200 BC, and Sir Bharata speaks Bharata's book entitled Natya Sastra, it told from a conversation as continuous almost 20 th century.

Aschroft et al., in Ratna[13] said that in India, orientalism, and postcolonialism to advance too far. Orientalism was begun after the East Indies Company (EIC) wins Bengali on the year 1757. Therefore, all the colonial administrator government could understand natives culture; consequently, it did understanding and translation to Persian language texts and Sanskrit texts to the English language.

\section{How to read postcolonial text ways}

Ashcroft et al. in Ratna[13] showed how "Ways of postcolonial text reading are two types." Those are 1. read text that called traditional domain, specific in according to social effect or damages, and 2. read as postmodern domain subversion, repeating of reading, to discourse, to symbolize system and fiction styles which were there and they gave examples as metaphor, allegory, irony, etc.).

Faruk[5] explained that "researcher to begin researcher's essay according to the research method that put in 2 steps, preparation step and research being held".

\section{Close reading of Tagore's "Freedom"}

Tagore's poetry is entitled "Freedom" from the first point of view. "Freedom" is associated with nationalism and humanity. Therefore, Tagore's poetry presents a postcolonialism literary work in which hope and prayer become one. Freedom of fear is the denotation, and the connotation of freedom of fear is what he can give to his motherland. Tagore's poetry also employs "motherland" as its diction. The denotation of the motherland on the poetry in India, according to Rabindranath Tagore biography as an Indian, though the poetry was short.

Mainland as the first idea in a stanza of Tagore's "Freedom" contains that reminder of what body tells the country's political atmosphere. Consequently, it is also associated with nationality relations. Socially, society has the legislature that fulfills the law and nationality consciousness. The elite group as constituent and vice of the community leads the government rule on the government structure. Ideology has affected the nationality of some countries, but inequality in wisdom often happens. Thus, Tagore's "Freedom" focus is freedom that Tagore spelled line from line.

Based on the title mentioned earlier, Tagore's "Freedom" draws its root from love to the motherland poem tradition with dream as its theme. However, it is also different from traditional nationalism poetry that usually depicts self-promise to the motherland. Thus, Tagore's poetry exposes his dream that confidence and witness become true freedom instead of national Independence from the ideological perspective. The atmosphere of freedom is so intense instead of Independently on some country socially.

Besides, Lehman's "Freedom" is a free verse or open form poetry. According to Kennedy and Gioia[9], a free poem or hollow form is composed 
based on free conventional rime and meter. They tell from their quote that "Writing in open form, a poet seeks to discover a fresh and individual arrangement for words in every poem". Therefore, Tagore's "Freedom" presents a fresh and free idea because the poem does not follow conventional verse rules. The creativity of line and allegory is counting the following research from close reading. It is strengthening the title and other things that the writer explains in his universe.

The point of view on the poetry is first, I. The subject expresses Tagore definitively, to feel and speak to the country's atmosphere. The line explains that Tagore recreated his freedom dream, India, because Rabindranath Tagore is a Bengali and was born in India. Realism and how to say love to the motherland were affected, and he claims to India from running from his fear. It is like not confidence. He does not spell his identity by saying he was born and to live in his country direct.

The postcolonial scene, which begins first, is the power of the motherland. The motherland is an area where some nations are proud, and they can tell the evidence, war, darkness of colonialization that affected someplace, and religious activity. It grows as a degree of nationality, and postcolonialism means sharing that writer reflection to national life is primary, and the future was asked. The spirit of nationalism has a structure as what, how, where, when, and who. The motherland has some national identity, and he does not tell the postcolonialism evidence nor political struggle.

The first to second of all lines, freedom from fear, and he claimed the spirit as love and dedication to his country. The soul is how to start, how to begin, and what is the final treatment on his life. Freedom from fear, and he claimed the spirit to his country on first data.

The second data burden ages as to how someone grows from child to adult. It was told from Tagore on the third line about how Tagore feels that adult becoming is normal. Reality ages affected to research that moments will come and fulfill generations. The second data would find on the third and fourth lines.
Lines that contain a figure of speech, as hyperbole, allegory, personification, metaphor, etc.

Freedom from fear is the freedom

I claim for you my motherland!

Freedom from the burden of the ages, bending your head,

Breaking your back, blinding your eyes to the beckoning

(Tagore, 1861-1941, stanza 1, lines 1-4)

(Courtesy: Pearls of Wisdom,2012)

In stanza 1 lines 1-4 "Freedom" is directly compared to various associations. Various denotations and metaphors are bending your hand, breaking your back, blinding your eyes to the beckoning.

The third sentence of sentences as freedom from the ages' burden meant getting the victory from old age denotative consequently. Then, bending your head is how the writer falls the face under, denotative consequently. Breaking your back is how the writer feels to see a far from how the front is calling him, denotative consequently. Blinding your eyes to the beckoning is how the writer or poet encloses eyes to speak about close to see some pictures, denotative hence and beckoning is how someone gives a signal from an action or theatrically symbol. Denotation meant a dictionary meaning in every word.

Then, beckoning is how the writer spells about something in beckoning. In the following lines, he speaks.

\section{Blinding your eyes to the beckoning call of the future; \\ Freedom from the shackles of slumber \\ wherewith \\ (Tagore 1861-1941, 1 stanza, lines 4-7) \\ (Courtesy: Pearls of Wisdom,2012)}

He speaks that to close your eyes as no one has eyes to the next signal, call the future. The future was suddenly the wrong moment, and bad luck in his country, India, is denotative. He writes freedom from the shackles of slumber, wherewith. Wherewith free life from the one of a pair of metal rings linked from a chain, and slumber is a verb, and it is a pair of metal rings linked from a chain, and it sleeps on the way.

After that, wherewith as he wrote, how someone runs and jumps from a pair of metal rings linked from 


\section{Effendie, Haris Prasetya \\ Freedom Domination of Rabindranath Tagore's Freedom Poetry: A Postcolonial Approach}

a chain, it is always to be there when a demonstration is held in the front of the government palace. Personification sentence is located on the shackles of slumber because a pair of metal rings linked from a chain was expressed as whose sleep, not underlying. Direct, metaphor is also located on the shackles of slumber wherewith before the following sentence because shackles of slumber are one position as a sea coral and shrubs from level and personification how shackles are stronger fear from sleeping on the street. Therefore freedom is genuinely there to move on and stop the wratch.

He speaks on the following line

you fasten yourself in night's stillness,

Mistrusting the star that speaks of truth's

adventureous paths;

(Tagore, 1861-1941 1 stanza: lines 8-10)

(Courtesy: Pearls of Wisdom,2012)

You are the reader in the poetry as the reader. Fasten is run competed in stillness. Stillness is how someone counts the strengthening to fight. Seriously how to fight yourself in many ways and much duration. Politically, human rights to alive and free from fear is yet. Mistrusting the star is translated from no follow the lead, disagree from the future, and following the formulation of glorious necessary to nationality.

Metaphor is different from personification because the meter of comparison is how adrenaline of life is doing something and the class of perspective and structural on a problematizing. Personification is a figure of speech denotative, consequently talked from mistrusting the star that speaks of adventurous paths. A star was questioned from the author's reflection to the reader that listened to him. The was doubting star is paths as streets that turn much adventurously adrenaline. Adventurous adrenaline is the more dangerous new imperialism that contained the voice of exploitation. It talked about severe high matters to the nationality to break up the country's nationality union.
To finish it, he speaks that he was nationality from the poetry on following lines

Freedom from the anarchy of destiny

whole sails are weakly yielded to the blind

uncertain winds,

and the helm to a hand ever rigid and cold as

death.

(Tagore, 1861-1941,1 stanza, lines 11-15)

(Courtesy: Pearls of Wisdom,2012)

Tagore's wishes reflection was collected as new structural life. How he sees destiny adventurously was including from first to middle of lines in Tagore's poetry. Anarchy of future is imperialism that is there on the motherlands destiny. It is concluded as the new imperialism of the postcolonial age. Society as the universe and universal structure could exemplify nationalism from cross characterization, cross ideas, cross politicization. But the country was illustrated the rule of humanity postcolonial. The Anarchy of destiny is imperialistic that passes yields weakly to the future that theirs is not to them but new imperialistic as a royal owner. So, poverty was everywhere.

In the final lines, he spoke deeply.

Freedom from the insult of dwelling in a puppet's

world,

where movements are stated trough brainless

wires,

Repeated through mindless habits,

Where figures wait with patience and obedience

For the

Master of show

To be stirred into a mimicry of life.

(Tagore, 1861-1941,1 stanza, lines 16-24)

(Courtesy: Pearls of Wisdom,2012)

The final lines to the lines were a calling due to the position underlying the last hope from Tagore. Long he writes as he had the power to the next era on his motherland. He speaks that freedom is his hope from failure. The mysterious future was not prepared from one sentence direct except it is planned. As a nation, the nation has a period of victory and sadness. He said that the next wish is freedom from the rude remark or action of life where considered, into a dark world 
from new dependence. Wires are metal in the form of a thin thread as a telegram.

He reminds that the true leaders to India are, according to Prime Minister, come to the India palace and repeat through mindless habits since figures are leader or boss man, they wait with patience and obedience for the problem of life and people for the Master of a show as a human or demonstrate when a demonstration is being held that ask the law and human right necessary. To be stirred is to be moved into a mimicry of life is the adrenaline of life from many problems and research too much.

\section{Reconstructive Reading of Tagore's Freedom}

Any quotes in reconstructive reading, therefore, the following research understanding was supported. Critical thinking is coming about how freedom from fear is, first of all. True, the poetry has subjectivity, and connotation is there to hide the secret according to aesthetic thinking. Critical thinking to following understanding about the royal secret is advancing India and the government to listen, people, heart voices.

Reynolds[14] analyzed that Tagore shows in the poem "Freedom" that he would like his country, India, to be free from colonial rule." Reynolds speaks again that Tagore tells his audience the attributes that they, the Indian people, must nurture to become free. His fellow countrymen have to create conditions within themselves to lay the foundations for a free state. This mindset includes freeing themselves from fear. It meant having a clear vision rather than being "blind" about the "call of the future".

He achieves that it meant his countrymen must awaken and start trusting the adventure of pursuing freedom. It also means giving up "brainless" living in which the colonial masters control.

Bruce[2] explains that Tagore shows in the poem "Freedom" that he would like his country, India, to be free from colonial rule. Bruce talked "In the first two lines of the poem, he refers to India as the "motherland" and states that he wants India to be free from fear. Bruce showed "his use of alliteration, or repetition of the "f" sound in words "freedom," "from," "fear," and "freedom" again in the first line, emphasizes the urgency of his call for Indian
Independence". Bruce said "the word "freedom" is repeated throughout the poem to express the poet's deep wish for his country to be independent. Bruce shared the idea "in the third line, he builds on the image of India as an aging mother, and he wants her to be free from the "burden of the ages," which refers to the yoke of English control of India".

Bruce[2] explained, "the aged woman who represents India bends her head, bends her back, and blinds her eyes under the burden of colonialism". Bruce's centralization of the role that "these lines also use alliteration with the repetition of the "b" sound". Tagore speaks of how India does not see the future or imagine a brighter future for herself from blinding her eyes.

Bruce achieved about the shackles of slumber here, "Instead of looking forward, India sleeps with what Tagore calls "shackles of slumber," or time spent not thinking of her future". Instead, India is fastening herself "in night's stillness," meaning that the country is committed to the past and the current situation of colonialism. The nation "mistrusts the star that speaks of truth's adventurous paths," meaning that the country does not look around in its dark time (represented from the night) and imagine a brighter future for itself as independent.

Bruce answered, "when Tagore asks for "freedom from the anarchy of destiny," he means that he doesn't want his country to just blindly and passively follow the fate that has been given to it, and he compares this fate, or destiny, to a sailboat that has to follow winds that are blowing in every direction and that is captained from an uncaring hand". Bruce has an answer "this is a metaphor in which his country is compared to a sailboat following uncertain winds with an uncaring person at the helm".

Bruce answered following lines that "then, Tagore asks for freedom from India living in a "puppet's world," from which he means a world in which India is controlled from other countries and forces as a puppet is controlled from a puppeteer". The movements are orchestrated through "brainless wires," meaning that England controls India without thinking and from following "mindless habits," meaning customs that are followed without reason. 


\section{Effendie, Haris Prasetya \\ Freedom Domination of Rabindranath Tagore's Freedom Poetry: A Postcolonial Approach}

Bruce spelled "in this extended metaphor comparing India to a puppet show, figures, who are clearly Indians, wait obediently just to follow the master of the show, meaning their English rulers". Therefore, the Indians live "a mimicry of life," meaning an inauthentic life controlled by others.

\section{CONCLUSION}

Rabindranath Thakur was born as a Bengali poet. Rabindranath Tagore (1861-1941) talked about the atmosphere of India reflected how the universe becomes the witness of a writer to readers. During the time, the action can be drawn as a figure of age and symbol of nationalism because of how much memory could contain between ideology, nationalism, and soul of feeling so the spirit of Independence could begin. The son of the religious reformer Debendranath Tagore, he early began to write verses, and, after preliminary studies in England in the late 1870s, he returned to India. He returned to India to begin literary works. He could start the literary work because of his spirit to reflect the history of nationalism and religion that contains God and God's serves.

The poetry freedom is a Rabindranath Tagore's wishes and hopes for the Indian constitutional future. Sir Rabindranath Tagore in 1918 said in an address delivered at the university he finds on his $70 \mathrm{~s}$ birthday, "I have it, it is true, engaged myself in a series of activities. But the innermost me is not to be found in any of these. Finally, at the end of the journey I am able to see, a less much clearly, the orb of my life. Looking back, the only thing of which I feel certain is that I am a poet". The new imperialism attacked the 19-20th century when postcolonial countries have recent history.

Tagore's poetry is entitled "Freedom" from the first point of view. "Freedom" is associated with nationalism and humanity. Tagore tells his audience the attributes they, the Indian people, must nurture to become free-having a clear vision rather than being "blind" about the "call of the future." His use of alliteration, or repetition of the " $\mathrm{f}$ " sound in words "freedom," "from," "fear," and "freedom" again in the first line, emphasizes the urgency of his call for Indian Independence.
To be free from the "burden of the ages," which refers to India's yoke of English control. The aged woman who represents India bends her head, turns her back, and blinds her eyes under the burden of colonialism. The lines also use alliteration with the repetition of the "b" sound. Instead of looking forward, India sleeps with what Tagore calls "shackles of slumber," or time spent not thinking of her future. The country is committed to the past and the current situation of colonialism.

The country does not look around in its dark time (represented from the night) and imagine a brighter future for itself as an independent. He doesn't want his country to just blindly and passively follow the fate that has been given to it, and he compares this fate, or destiny, to a sailboat that has to follow winds that are blowing in every direction and that is captained from a cold hand. This is a metaphor in which his country is compared to a sailboat following uncertain winds with an uncaring person at the helm. A puppeteer controls a world in which other countries and forces control India as a puppet. England holds India without thinking and following "mindless habits," meaning customs followed without reason.

Metaphor comparing India to a puppet show, figures, who are Indians, wait obediently to follow the master of the show, meaning their English rulers. A mimicry of life," meaning an inauthentic life controlled by others. Connotation and denotation have different signals, and it could be found as one of all moral values in some poetry. The figure of speech helped intrinsic elements, from how the plot is there, figuration or characterization of figures turns on to next idea that was written from the author. The figure of speech helped extrinsic elements since it helped the reader give the lovely supper to a guest, how the author spelled the moral value from his universe in literary work to the reader, and the research looks at it from an expressive approach to postcolonialism theory.

An independent postcolonial country to resolve the problematizing from tolerance and peace. How to live the tolerance and new freedom of peace, from seeking cross-culture and cross characteristic knowledge and finding benefits of technology adaptation every season and remarkable happening in 
every postcolonial country. Hopefully, Tagore's poetry was applied and to bless India through too much procedure and risk.

\section{REFERENCES}

[1] Indian mutiny. (2020, May 3). Britanica.com. https://www.britannica.com/event/IndianMutiny

[2] Bruce, O. (2020, October 18). Read "Freedom" by Rabindranath Tagore: Analyze the poem line by line. Enote.com.

https://www.enotes.com/homework-help/readfreedom-by-rabindranath-tagore-analyze-poem$\underline{867806}$

[3] Nicole, H. (2020, October 6). Allegory Vs metaphor: What's the difference? Become a Writer Today.com.

https://becomeawritertoday.com/allegory-vsmetaphor/

[4] Cambridge Dictionary. (2020). Nationality. https://dictionary.cambridge.org/dictionary/eng lish/connotation

[5] Faruk. (2017). Metode penelitian sastra: Sebuah penjelajahan awal. Yogyakarta: Pustaka Pelajar. https://journal.unesa.ac.id/index.php/ipi/article $\angle$ view/589

[6] Gammon, K. (2012, April 7). What is freedom. Live Science.

https://www.google.com/amp/s/www.livescien ce.com/amp/21212-what-is-freedom.html

[7] Ivision, D. (2020, October 4). Postcolonialism historical period. Britannica.com. https://www.britannica.com/topic/postcolonial ism

[8] Klarer, M. (2004). An introduction to literary studies, $2^{\text {nd }}$. London: Routledge.

https://api.taylorfrancis.com/content/books/m ono/download?identifierName $=$ doikidentifierV alue $=10.4324 / 9780203068915 \&$ type $=$ googlepdf
[9] Kusumaningrum, P. D. \& Mulyani, S. (2016). Problematizing de Beauvoirs myth of woman through gender relation in David Lehmans "when a woman loves a man". Journal of Language and Literature Vol 16(2), p. 201-226. https://ejournal.usd.ac.id/index.php/JOLL/article/view/ $\underline{365}$

[10] What Is connotation? Learn about connotation in writing with examples. (2021, March 21). MasterClass.

https://www.masterclass.com/articles/what-isconnotation-learn-about-connotation-in-writingwith-examples

[11]Munthe, A. M. \& Lestari, R. (2016). The impression of rhetorical devices in Wendy's taglines. Journal of Language and Literature, Vol 16(2), p. 165-177. https://ejournal.usd.ac.id/index.php/JOLL/article/view/ $\underline{363}$

[12]Rabindranath Tagore: Biographical. (2020, October 10). The Nobel Prize. https://www.nobelprize.org/prizes/literature/1 913/tagore/biographical/

[13]Ratna, N. K. (2008). Postkolonialisme Indonesia: Relevansi sastra. Yogyakarta: Pustaka Pelajar.

[14]Reynolds, D. (2020, October 18). How is the theme of patriotism conveyed in Tagore's poem "freedom"? Enote.com.

https://www.enotes.com/homework-help/howtheme-patriotism-conveyed-tagores-poemfreedom-1129241

[15]Robinson, W. A. (2020, October 10). Rabindranath Tagore Bengali poet. Britaninica.com. https://www.britannica.com/biography/Rabind ranath-Tagore

[16]Said, E. W. (2014). Orientalism. New York: Vintage Books. 
[17]Setiowati, R. V. \& Wardani, E. D. (2016). Capitalism as an ideology criticized through allegory in Ryonosuke Akutagawas Kappa. Journal of Language and Literature, Vol 16(2), p. 178-200.

https://ejournal.usd.ac.id/index.php/JOLL/article/view/ $\underline{364}$ 